\title{
Challenges of federal coordination of Social Assistance Policy: the states' role in financing
}

\author{
ISABELA DE VASCONCELOS TEIXEIRA ${ }^{1}$ \\ BRUNO LAZZAROTTI DINIZ COSTA ${ }^{2}$ \\ 1 Prefeitura Municipal de Belo Horizonte, Belo Horizonte - MG, Brazil \\ 2 Fundação JoÃo PINHEIRO, BELO HORIZONTE - MG, BRAZIL
}

\begin{abstract}
This article analyzes the degree, variation, and determinants of the states' co-responsibility in financing the social assistance policy. The study verifies whether the mechanisms of coordination and federative induction contributed to this process. Based on a literature review on federalism and determinants of decentralization of social policies in Brazil, we conducted a documentary analysis and examined quantitative data on the states' configuration and co-financing of social assistance policy using the State Social Assistance Funds between 2000 and 2018. The study explored whether induction and coordination mechanisms contributed to increasing expenditures in the sector. On the one hand, the results showed that these mechanisms have an impact on the states' financing of social assistance policy. On the other, they generated great heterogeneity among the states regarding their responsibilities in the federal funding arrangement.
\end{abstract}

Keywords: Social assistance. Financing. Federative coordination.

\section{Desafios da coordenaçãofederativa da Política de Assistência Social: o papel dos estados no financiamento}

\section{Resumo}

O artigo analisa o grau, a variação e os determinantes da corresponsabilidade do financiamento da política de assistência social pelos entes estaduais, verificando a contribuição dos mecanismos de coordenação e indução federativa, apontados por vários autores como fatores de sucesso. Com a revisão da literatura sobre federalismo e determinantes da descentralização de políticas sociais no Brasil, realizou-se uma análise documental e de dados quantitativos sobre a configuração e o cofinanciamento realizado pelos Estados, por meio dos Fundos Estaduais de Assistência Social, entre 2000 e 2018. Analisou-se ainda se os mecanismos de indução e coordenação representaram um aumento dos gastos no setor. Os resultados apontaram que, de um lado, eles foram capazes de produzir efeito no conjunto dos estados, mas, de outro, geraram grande heterogeneidade nas responsabilidades federativas entre eles.

Palavras-chave: Assistência Social. Financiamento. Coordenação federativa.

\section{Desafíos de la coordinación federal de la Política de Asistencia Social: el papel de los estados en el financiamiento}

\section{Resumen}

Este artículo analiza el grado, la variación y los determinantes de corresponsabilidad del financiamiento de la política de asistencia social por los gobiernos de los estados, verificando si los mecanismos de coordinación e inducción federativa contribuyeron en este proceso, señalados por varios autores como factores de éxito. Con base en la revisión de la literatura sobre el federalismo y los determinantes de la descentralización de las políticas sociales en Brasil, se realizó un análisis documental y cuantitativo de la configuración y cofinanciamiento por parte de los estados a través de los Fondos de los Estados de Asistencia Social, entre 2000 y 2018 . Asimismo, se examinó si los mecanismos de inducción y coordinación representaron un aumento del gasto en el sector. Los resultados mostraron que, por un lado, tuvieron un efecto en el conjunto de estados, pero, por otro, generaron una gran heterogeneidad en las responsabilidades federales entre ellos.

Palabras clave: Asistencia social. Financiación. Coordinación federativa. 


\section{INTRODUCTION}

The implementation of public policies in federal states has to deal with the challenge of combining the autonomy of the entities with the need for coordination between them. The analysis of federative relations and intergovernmental coordination mechanisms in any federal system is fundamental for understanding the scope and inequalities in access and the quality of universal and decentralized social policies.

In the case of Brazil, the Social Protection System was expanded and reconfigured based on the Federal Constitution of 1988 (CF-1988), guided by the institution of a broad list of social rights and the guidelines for decentralization and universalization of offers and social participation in decision-making processes. For the purposes of this paper, the inclusion of the Social Assistance Policy (PAS) within the scope of Social Security is highlighted.

Several studies have analyzed the process of decentralizing Brazilian social policies based on redemocratization (ALMEIDA, 1996; ABRUCIO, 2006; ARRETCHE, 2000, 2006; FRANZESE and ABRUCIO, 2009). Given that the municipal movement gained strength during the period, the implementation of the decentralization directive emphasized the responsibilities for the provision of social services by the municipalities, transferring functions from the federal government - and, in some cases, from the state - to the municipality over the following decade. Thus, the studies focused mainly on the performance of municipalities in terms of social spending and the expansion of public services offered (GOMES and MACDOWELL, 2000; SOUZA, 2004). Considering, however, that the Brazilian federative system is close to the cooperative model - in view of the large number of shared competences defined by CF-1988 -, the profile and effectiveness of social policies depend on the participation, articulation and priority assigned to each policy by the three federated entities.

From this point of view, the role and participation of state entities in the federative arrangement of organization and provision of social services in Brazil is still the subject of debate. As stated by Souza (2018, p. 271), "there is a great lack of knowledge about the role of states in social policies, especially when compared to other spheres of government". Thus, it is relevant to deepen the understanding of the role played by state entities in this field.

In the case of PAS, the process of decentralization and institutionalization of this policy took place late, in comparison with other social policies, such as health and education (ALMEIDA, 1996; ARRECTHE, 2000; PALOTTI and COSTA, 2011). Analyzes of this process have pointed to the importance of the national social assistance system, the formulation and coordination performed by the federal government and its effects on the expansion of the implementation of services, as well as strengthening institutional capacity of subnational entities (ALMEIDA, 1996; ARRETCHE, 2000 and 2006; FRANZESE and ABRUCIO, 2009). However, its effects were uneven on states and municipalities.

Municipalities have demonstrated an active and consolidated role in the implementation of services and socio-assistance benefits; increasing institutional capacity and expanding human and financial resources; in the process of negotiation and federative articulation (JACCOUD, LICIO and LEANDRO, 2018) - finally, in the federative responsibilities of this sectorial policy. In the case of states, the few studies dedicated to the role of this entity in the process of decentralization and institutionalization of the policy identify that adherence to the Unified Social Assistance System (Sistema Único de Assistência Social - SUAS) by state governments was not accompanied by the same level of institutional strengthening as presented by federal and municipal entities (SILVA, 2015). In addition, the states assumed a supporting role (SOUZA, 2018) in the formulation and implementation of social assistance, with low institutional and budgetary commitment of its federative responsibilities (JACCOUD, LICIO and LEANDRO, 2018).

The authors explain that this is due to the residual and complementary role delegated to the states in the regulations and policy design, with ample discretion and low political incentives for its performance. Since they have a secondary obligation in the formulation of the policy and almost none in the implementation and execution of social assistance services, the states receive low political credit for performing their functions.

Among the federal responsibilities assumed by the state governments, the PAS co-financing stands out, which must be shared among the three federated entities, following the cooperative logic defined by CF-1988. In the 2000s, Brazil experienced a period of growth in spending on social assistance in relation to total spending in the three spheres of the federation (KHAIR, 2013). In the set of spending on social assistance, however, Mesquita, Martins and Cruz (2012) pointed out that the smallest participation is from the states. 
In addition to the obvious importance of financing for the expansion and qualification of public policy implementation, several studies on the PAS federative coordination and induction mechanisms reveal the financing model for SUAS as one of its central mechanisms (JACCOUD, LICIO and LEANDRO, 2018).

In view of the briefly exposed context and aiming to contribute to understanding the reasons why states have assumed a residual and supporting duty in the implementation of SUAS, this article seeks to analyze the degree, variation and determinants of the co-responsibility of financing within the scope of social assistance policy by state entities. We use as theoretical subsidies, studies on the process of decentralization of social policies in Brazil and, as an analytical key, the concepts of federative coordination and induction, with emphasis on PAS.

\section{THE DECENTRALIZATION OF THE SOCIAL ASSISTANCE POLICY AND THE CONFORMATION OF ITS FINANCING MODEL}

In the field of social policies, the processes of decentralization, as a way of distributing power, resources and attributions among the entities of a federation, have occupied a prominent place in the research agenda. Today, it is possible to point out a relative consensus around the statement that, more than defining a political system as federal, unitary, or classify a policy as more or less decentralized, are the institutional arrangements and coordination mechanisms that guide each specific policy that determine the character of intergovernmental relations, as shown by, among others, the work by Arretche $(2000,2006)$.

From a political-institutional point of view, CF-1988 inaugurated a new moment in Brazilian federalism (ABRUCIO, 2006), marked by the decentralization guideline combined with a strong municipalist wave and by the complexification of intergovernmental relations. In this context, the decentralization of social policies was strongly influenced by the previous legacy of sectoral policies (ARRETCHE, 2000) and the adoption by the federal government, of a nationwide plan that clearly defines how the exclusive and shared attributions would be distributed among the federal entities (ALMEIDA, 1996). Intergovernmental coordination mechanisms were also taken into account - that can alleviate conflicts arising from forms of competitive performance and political bargaining (FRANZESE and ABRUCIO, 2009) - and induction, fundamental in a context of growing autonomy of subnational entities, that need to be encouraged to adhere to the processes of transferring functions in the management and execution of social policies (ARRECTHE, 1996).

Furthermore, the literature points out that the model of fiscal federalism adopted since the CF-1988 also influenced the process of decentralization of social policies, defining how the fiscal and tax resources should be shared among the entities, allowing (or not) that everyone obtain a financing capacity compatible with their new responsibilities (ARRETCHE, 2010; REZENDE, 2010). As for revenue sharing, there was a strengthening of the collection capacity of states and municipalities due to changes in the tax authority of each entity and, mainly, for the distribution of revenues from constitutional intergovernmental transfers.

Its effects, however, are limited, as transfers contribute to reduce inter-regional imbalances, but at the intra-regional level they tend to favor small municipalities, not necessarily the poorest (GOMES and MACDOWELL, 2000). In addition, over the 1990s, states suffered significant losses in revenue sharing, which currently limit their ability to influence and intervene in the development of public policies at the local or regional level (MONTEIRO NETO, 2013).

CF-1988 did not include a clear project for the redistribution of charges to states and municipalities, which meant that they did not immediately assume their duties in the process of decentralizing social policies. To reverse this, the Union developed important strategies, such as strengthening national regulation and creating conditional federal transfers (ARRETCHE, 2005) - these had a double effect: they stimulated the adhesion of subnational governments to decentralized social policies and presented expressive redistributive results, although not enough to overcome the country's structural territorial inequalities.

Thus, intergovernmental transfers can be seen as strategic coordination mechanisms in the process of decentralizing social policies, in addition to acting as a factor in strengthening the institutional capacity of these entities. Furthermore, the fiscal 
crisis faced by Brazil during the period of re-democratization is also seen as an important condition for the transformation of the federal system (ALMEIDA, 1996). After 1988, economic constraints, added to the loss of resources by the Union caused by fiscal decentralization, were predominant, so that Abrucio $(2005$, p. 194) writes that the federal government, in the early 1990s, sought to transform decentralization into a transfer of functions, termed at the time as disassemble operation.

In the case of social assistance, Almeida (1996), Arrecthe (2000) and Palotti and Costa (2011) say that the process of decentralization and institutionalization of this policy took place late, compared to other social policies like health and education. This was due, in particular, to the sector's previous legacy, marked by the clientelist use of social interventions towards the population and as a "bargaining chip" between local and central governments that tended to hinder the overcoming of political bargaining practices among federated entities.

Arretche $(1996$, p. 47) points out that the federative bases of the Brazilian State impacted the process of decentralization of social policies, since, "protected by the principle of sovereignty, states and/or municipalities assume the management of public policies under the prerogative of accession, therefore needing to be encouraged". In addition, the party and competitive Brazilian political system tends to stimulate intergovernmental conflicts and increase social policies as an instrument of political bargaining. Thus, public responsibility for PAS management has become one of the bargaining elements. In this sense, each sphere seeks to minimize its costs, transferring them to other entities, and maximizing its benefits, understood as political gains generated by the offer of shares to the population. The creation of strategies to induce the adherence of entities to policies plays a central role for its success. In this way, the functions of the central level should be strengthened, and not their emptying, as might be expected when carrying out the division of functions between the federated entities.

In view of the arguments identified in the literature, the design of intergovernmental relations is highlighted in many studies on social policies, as in the case of PAS. Central factors are the coordination and induction role assumed by the federal government, the institution of a national public policy system, the strengthening of national regulation and the creation of conditional federal transfers - these have become an important mechanism for inducing the adhesion of subnational governments, as in the case of PAS, which will be discussed below. Thus, the strategic coordination mechanisms in the process of decentralization of the PAS and its relationship with the financing model established will be addressed.

\section{MECHANISMS OF INDUCTION AND FEDERATIVE COORDINATION OF SOCIAL ASSISTANCE POLICY AND ITS RELATIONSHIP WITH THE FINANCING MODEL}

Since CF-1988, in its art. 204, it was clear that social assistance should be organized based on the guidelines for popular participation and political-administrative decentralization, "the coordination and general rules are the responsibility of the federal sphere and the coordination and execution of the respective programs at the state and municipal levels, as well as philanthropy and social assistance non-governmental organizations". Only with the approval of the Organic Law on Social Assistance (Lei Orgânica da Assistência Social - LOAS), in 1993, however, was a clearer proposal for the reorganization of functions between the three levels of government instituted. Such law defined the bases of organization and operationalization of the policy, advancing the definition of the responsibilities of federative entities. Its decentralized model explained the clear option for municipalization, by prioritizing the municipality as the central locus of the execution of social assistance services, and defined a new institutionality, in which states were delegated a residual function (ARRETCHE, 2000).

Before redemocratization, the financing of social assistance was characterized as its form of management and operation social assistance was a sector of fragmented and discontinued actions, centralized at the federal level and based on the covenant logic. Since most of the offers were made by philanthropic and religious non-governmental organizations, the contribution of resources in assistance actions consisted mainly of the transfer of resources to these organizations through covenants. Assistance interventions carried out by the public administration were few and disjointed, alternating between centralized actions at the federal level or superimposed at the subnational level, due to the lack of a national policy that would give them coordination or unity.

The financing transformation of this policy started with CF-1988 and with the publication of LOAS in 1993, that defined guidelines for the adequacy of financing to the new concept of social protection and to the new management and execution 
model proposed for the area. The guidelines for the institution of the single command of social assistance management stand out, including resources, and the shared character of financing, in which the three federated entities must contribute to the cost of services and benefits.

One of the innovations in financing brought by LOAS was linking, in the case of the Union, the transfer of resources to subnational entities to the institution within its scope of management instruments - the council, the plan and the social assistance fund, known as CPF. Inspired by the Unified Health System model (Sistema Único de Saúde - SUS), the CPF has become an important mechanism to induce the adhesion of subnational entities to PAS, through the strategy of enabling states and municipalities. ${ }^{1}$

More than a decade later, the creation of the National Social Assistance Policy (Política Nacional de Assistência Social - PNAS), in 2004, as well as the approval of the Basic Operating Standard (Norma Operacional Básica - NOB), in 2005, and the National Type of Social Assistance Services, in 2009, played a key role in defining the scope of social assistance offers and defining management rules and procedures necessary for their operation. Thereafter, progress was made in consolidating the sector's financing model. These regulations established the institutional bases for the formation of SUAS. The PNAS and the NOB 2005 detailed the roles of national and subnational entities in the process of implementing SUAS. The municipalities were responsible for implementing state units to promote social protection services - the Social Assistance Reference Centers, manage the network of services offered by social assistance non-governmental organizations and co-finance the offers. The Union was responsible for giving the general guidelines of the system, in addition to co-financing and providing technical support to state entities. States should co-finance and provide technical support and training for municipal entities, as well as implementing regionalized social assistance services - in the case of municipalities with a small population, whose demand did not justify the implementation of local services.

The PNAS and the NOB 2005 promoted a redefinition of the bases of financing that made it possible to adapt it to the management model proposed by SUAS. Tavares (2009) identifies that it was with the institution of the bases for the organization of social assistance as a unified system in PNAS that the new phase was inaugurated. Thus, the objective of the financing model became the effective application of financial resources to fund well-defined and continued social assistance offers. Another important point was the greater clarity in the definition of the responsibilities of subnational entities in the co-financing of offers and in the way they are operationalized. Co-financing, operated through regular and automatic transfers - that is, despite the signing of a legal instrument or similar-, with predefined values and predictability, has become essential to the policy model. The definition of the value and the municipalities and states benefited should be based on diagnoses and social indicators, in order to build more effective interventions to combat social inequalities and strengthen social assistance as a State policy. In addition, co-financing started to be organized according to specific minimum mandatory amounts for basic social protection services, special social protection of medium and high complexity.

In 2011, the innovations brought by the SUAS implantation experience were incorporated into LOAS and led to a new NOB agreement in 2012. Among the main changes brought to LOAS in financing, the emphasis on co-financing and cooperation between entities (art. 6); in the form of automatic transfers from fund to fund, important to ensure the predictability of resources; and the creation of co-financing to improve management. ${ }^{2}$ NOB 2012 defined the role of each federated entity in co-financing, conferred greater flexibility to subnational entities through financing sets, highlighted the agreement on priorities and goals for the establishment of a new collaboration regime between the entities - through technical and financial support-, as well as detailed operational aspects aimed at improving social assistance funds and the role of managers (BRASIL, 2013).

The integration between the process of inducing adherence to the system (habilitation), the creation of institutionalities (CPF) and the institution of co-financing via continuous transfers, combined with strategies to induce the strengthening of management capacity and financial incentive, that acted as catalysts for the municipalities' adhesion to SUAS. Between 2003 and $2009,99.4 \%$ of Brazilian municipalities and 26 states - plus the Federal District - had already joined. The vertiginous growth of the social assistance network observed between 2005 and 2016 - for example, the Social Assistance Reference Centers (Centros de Referência de Assistência Social - CRAS) increased from 4,195 units in 2007, to 8,240 in 5,225 municipalities in

\footnotetext{
${ }^{1}$ Started with NOB 1997, it was with SUAS and NOB 2005 that the rules and incentives for qualification became clearer, through the definition of management levels linked to population size and management mechanisms, driving ongoing decentralization.

${ }^{2}$ The creation of the Decentralized Management Indexes of the Bolsa Família Program (IGD-M and IGD-E) and SUAS (IGD-SUAS) was an important driver of improvements in the management of the system by conditioning the transfer of federal resources to the performance of management indicators.
} 
2016, with a territorial coverage of around $93.8 \%^{3}$ - and federal resources, which increased $168.9 \%$ between 2000 and 2012 (KHAIR, 2013), also seem to point to the success between combining induction strategies with financial incentive.

From the point of view of federative coordination mechanisms, Jaccoud, Licio and Leandro (2018) add the importance of strengthening PAS regulation for its conformation. It was only with the approval of the NOBs that such federative mechanisms were instituted in the PAS, contributing to the strengthening of intergovernmental relations:

The definition of roles and responsibilities of federated entities took shape in the agenda, as well as the agenda for intergovernmental interaction and coordination. Shared management was adopted as a reference for the organization of offers, materialized with the structuring of a "single system", aggregating the three spheres of government. Decision-making and the creation of regulatory instruments and intergovernmental agreement spaces were valued as strategies to promote coordination, encourage cooperation and boost adherence to and compliance with general policy objectives (JACCOUD, LICIO and LEANDRO, 2018, p. 24).

Franzese and Abrucio (2009) highlight the decentralization-inducing mechanisms created by the NOBs, following the steps of SUS. In addition to establishing management levels, qualification process and criteria and instruments for transferring resources from fund to fund, highlight the implementation of horizontal intergovernmental articulation instances - forums of municipal and state secretaries - and vertical - inter-manager commissions - , that favor the consolidation of an innovative federative articulation pattern, not foreseen in CF-1988.

The main federative coordination mechanisms created in SUAS are the negotiation and agreement: the Tripartite Inter-Management Commission (CIT), at national level, and the Bipartite Intergovernmental Commissions (CIB), at state levels. As defined in NOB SUAS 2005, all operational aspects of the decentralization process must be agreed upon by the commissions, understood as the result of negotiations established with the consent of the spheres of government involved, that presuppose the agreement of all involved (and not voting) and the publication of decisions in the form of resolutions.. Commissions or forums of representatives of municipal managers are part of the $\mathrm{CIT}$ and $\mathrm{CIBs}$, and forums of representatives of state managers are part of CIT.

Another checks and balances mechanism (ABRUCIO, 2006) created at SUAS corresponds to the Improvement Pact. Effected at CIT since 2007, this pact defines priorities for states and municipalities as to the direction of the PAS, in order to improve its offers and management. Priorities are translated into quantifiable goals, with defined monitoring deadlines and forms.

With regard to financing, in these instances there must be an agreement on eligibility and sharing criteria to define values and types of co-financing for municipalities. All new resources incorporated into the budget of the Union and the states should be taken up for discussion about the criteria for expanding financing coverage. After the agreement between the managers, such criteria must pass the approval of the respective social assistance councils. ${ }^{4}$

Jaccoud, Licio and Leandro (2018) highlighted that the financing corresponded to one of the main agendas on the CIT agenda and the improvement pact of the states from 2005 to 2016, such as the definition of eligibility criteria and resource sharing and the expansion of co-financing, respectively. However, the study concluded that the federated entities showed differences in terms of integration with SUAS and performance in the national agreement. As for the role of states, municipalism reflected a division of responsibilities in which states found themselves limited in the direct supply of services. This seems to have contributed for the municipalities to assume an active role in the processes of national agreement, as opposed to the states, which were limited to a residual function at SUAS, reflected both in a less active role in the shared decision-making process and in a limited adherence to strategic guidelines agreed at CIT, as is the case with the process of regionalizing the offer of medium and high complexity services and management improvement pacts (JACCOUD, LICIO and LEANDRO, 2018, p. 26).

The trend was to strengthen relations between the Union and municipalities and local governments, through a new bureaucracy and clientele. States remained a residual role in implementing PAS. Bearing in mind that the SUAS federative coordination model is strongly intertwined with its financing model and that co-financing corresponds to one of the main responsibilities

\footnotetext{
${ }^{3}$ Available on: <http://aplicacoes.mds.gov.br/sagi/publicacao_eletronica/muse/Censo2014/equipamentos.html>. Accessed on: June 17, 2020.

${ }^{4}$ Social assistance councils are important instances of social control that, as they differ from mechanisms linked to strictly federative relations, were not included in this analysis.
} 
left to state entities in PAS, the composition and functioning of state social assistance funds in Brazil will be analyzed important SUAS financing instrument -, the contribution of resources by the states and the co-financing to the municipalities. Thus, it is expected to verify the degree of federative responsibility assumed by the state entities.

\section{METHODOLOGY}

Given the objectives of the study, we intend to verify if the strong regulation and the institution of mechanisms of coordination and federative induction of SUAS led to the increase of the responsibility for the financing by the states. To this end, the social assistance funds' conformity to the criteria defined by the SUAS regulations and agreement instruments will first be analyzed.

The analysis of the conformation of the State Social Assistance Funds (Fundos Estaduais de Assistência Social - FEAS) started from the review of the current norms regarding the role of states in financing and the operational engineering of financing in these entities, based on the examination of data on the operationalization of these funds collected through the SUAS Census from 2010 to 2018. The SUAS Census corresponds to an electronic form, based on self-declaration, applied annually by the Ministry of Citizenship to monitor services, management and social assistance councils, instituted by Decree 7.334/2010.

Moreover, the analysis of the evolution of social assistance spending considers that the conformity of the constitution of social assistance funds in relation to the criteria defined by the SUAS regulations would imply an increase in the volume of resources in the sector. State expenditure data on the social assistance function provided by Finbra/National Treasury (expenditure). Finbra data show only aggregate spending by budget function. ${ }^{5}$ Thus, it was not possible to distinguish the amount of resources actually spent on social assistance funds and the amounts allocated to municipal co-financing.

Finally, we return to the SUAS Census data to analyze whether the compliance of the FEAS and the contribution of resources in the sector contributed to the effectiveness of co-responsibility of co-financing, verified through the transfer of financial resources from fund to fund to the municipalities under its jurisdiction.

\section{CONFORMATION OF STATE SOCIAL ASSISTANCE FUNDS IN BRAZIL}

Social assistance funds have become one of the main management instruments for this policy and the institutionalization of the SUAS financing model. The financing shared between the three entities started to be operationalized through it, using the Union's intergovernmental transfer strategy for states and municipalities and from states to municipalities under its jurisdiction.

Social assistance funds must be constituted as special funds (Law No. 4,320/1964). This device links the revenues allocated in the funds to the achievement of certain objectives or services, ensuring that the transferred resources will be used for what they are intended. It also determines the creation of an appropriation enshrined in the Annual Budget Law, which contributes to transparency and social control of resources.

NOB SUAS 2012 defined a series of criteria related to the allocation of the total income and expenses related to the set of social assistance actions in the fund; the definition of the public administration body responsible for the coordination of this sectorial policy as fund manager, under the guidance and control of the respective councils; the constitution of the fund as a budgetary unit; registration of the fund with the CNPJ as a matrix. The effectiveness of these criteria will be analyzed below.

One of the relevant factors among the sector's management guidelines is the unique command of social assistance actions and the decision autonomy of the portfolio manager, in administrative and financial terms. As pointed out by Sposati (2016), there is precedence for the vision of the sector as an activity and the resistance to recognize it as a public policy.

${ }^{5}$ Another caveat is the inaccuracy regarding the classification of the resources of the social assistance function, as pointed out by Mesquita, Martins and Cruz (2012), aggravated by the historical dispersion of PAS resources in different agencies. 
Regarding the management of FEAS, in most states the portfolio of social assistance is shared with other sectoral policies, with growth being observed between the years 2010, with 16 states, and 2018, with 24 states. This, however, did not mean that the secretariats did not create a specific formalized sector for budgetary and financial management nor that the PAS portfolio manager did not obtain control of spending in the sector. In 2010, 22 state management bodies had the sector implemented in the formal and informal structure. In 2018, all states had the sector constituted, even though the number of formalized ones dropped to 17. It also did not imply loss of the fund's management authority by the social assistance portfolio managerin 2010, in 20 states, the originator of expenses was the state secretary of the sector; in 2018, that number grew to 22. Such data on the formalization of the sector for the management of resources and the definition of portfolio managers as budget decision makers are indicative that PAS is relatively important in the organizational structure of the state executive power.

In relation to the operationalization of the financing, in 2014, all 26 states reached the fulfillment of the obligation to register the CNPJ of FEAS. In case the fund is constituted as a budgetary unit, in 2010, the FEAS of 25 states, with the exception of Goiás, answered the device. Goiás fulfilled the guideline in 2011. Although all the FEAS are a budgetary unit, this did not correspond to the fulfillment of the guideline for the execution of all the resources invested in social assistance in the fund. On the contrary, it corresponded to the most fragile factor in state financing. In 2010, thirteen states reported executing the entire budget at FEAS; the other thirteen, partially. In 2018, this scenario had changed little: only thirteen states reported executing the entire budget in the fund, while eleven partially executed and two did not: Rio Grande do Norte and Rio Grande do Sul.

This fragility was identified by Mesquita, Martins and Cruz (2012), that point funds parallel to the social assistance fund as one of the main challenges in the field of financial management of PAS. This demonstrates that the consolidation of a single budget by sphere of government that gathers resources destined to the area has not been achieved, which can weaken the management autonomy and the single command by the manager. Furthermore, the dispersion of resources makes social control of the policy difficult, since the funds must be submitted to the deliberation of the councils.

\section{AMOUNT OF STATE SPENDING ON SOCIAL ASSISTANCE}

In 2009, Mesquita, Martins and Cruz (2012) identified that state entities invested less resources in the sector - the Union represented $78 \%$ of public spending on social assistance, while municipalities and states accounted for $14 \%$ and $8 \%$, respectively. The high participation at the federal level is mainly related to the cost of monetary benefits: BPC and Bolsa Familia Program. Excluding these expenses - despite its importance for the reduction of inequality and poverty in Brazil - , are the municipalities that most allocate resources in services and eventual benefits, accounting for $49.6 \%$ of total public expenditure in the area in 2009. The states had the second largest participation, with $27.5 \%$, and the Union contributed with $22.9 \%$.

To identify the evolution of state expenditures in the PAS, the focus of this study, first an analysis of the financial expenditure classified in the social assistance function was carried out (expenditure), together with the analysis of the percentage of expenses classified in this function in relation to the general expenditure made by the 26 states in the period from 2005 to 2018 .

The table below shows that, in general, spending on social assistance represents a low percentage in relation to the total, with a minimum observed value of $0.27 \%$ in 2014 and a maximum of $2.21 \%$ in 2013 . There was a slight fluctuation in spending in the sector, between $0.77 \%$ and $0.72 \%$, between 2005 and 2012, with the minimum percentage observed in 2008, with $0.65 \%$. From 2013 to 2018, there is great variation in the proportion of spending, with an abrupt drop in 2014 and 2016. Between the beginning and the end of the analyzed period, we see that the proportional expenditure in the social assistance function fell, from $0.77 \%$, in 2005 , to $0.65 \%$, in 2018 . In absolute terms, there was a positive variation in annual growth between the period from 2005 to 2011, showing relative losses from 2012 - with the exception of 2013, in which there is a discrepancy in the values of total and sector spending. Nevertheless, the expenditure in the last year corresponded to $373.67 \%$ of the expenditure at the beginning of the series. 
Table 1

Evolution of expenditure committed to the social assistance function in absolute values and as a percentage of total expenditure in the 26 Brazilian states, from 2005 to 2018

\begin{tabular}{|c|c|c|c|c|c|}
\hline Year & $\begin{array}{l}\text { Total spending* } \\
\text { (BRL) }\end{array}$ & $\begin{array}{l}\text { Social Assistance } \\
\text { Spending* (BRL) }\end{array}$ & $\begin{array}{l}\text { Proportion of expenditure } \\
\text { in relation to total }\end{array}$ & $\begin{array}{l}\text { N. Social Assistance } \\
\text { Expenditure Index }\end{array}$ & $\begin{array}{l}\text { Annual evolution } \\
\text { \% Social Assistance } \\
\text { Spending }\end{array}$ \\
\hline & (a) & (b) & (b/a) & $2005=100$ & \\
\hline 2005 & $570,166,323,805.88$ & $4,385,210,516.95$ & $0.77 \%$ & 100 & - \\
\hline 2006 & $629,378,691,854.19$ & $4,896,971,496.46$ & $0.78 \%$ & 111.67 & $12 \%$ \\
\hline 2007 & $667,785,927,202.85$ & $4,819,132,333.77$ & $0.72 \%$ & 109.90 & $-2 \%$ \\
\hline 2008 & $749,453,939,152.10$ & $4,880,473,738.96$ & $0.65 \%$ & 111.29 & $1 \%$ \\
\hline 2009 & $747,781,962,655.42$ & $5,537,171,182.50$ & $0.74 \%$ & 126.27 & $13 \%$ \\
\hline 2010 & $871,973,309,085.05$ & $6,208,665,487.37$ & $0.71 \%$ & 141.58 & $12 \%$ \\
\hline 2011 & $856,514,265,359.87$ & $6,754,431,553.66$ & $0.79 \%$ & 154.03 & $9 \%$ \\
\hline 2012 & $910,805,005,815.75$ & $6,584,182,083.87$ & $0.72 \%$ & 150.15 & $-3 \%$ \\
\hline 2013 & $952,573,037,756.70$ & $21,056,384,623.26$ & $2.21 \%$ & 480.17 & $220 \%$ \\
\hline 2014 & $8,170,116,457,240.50$ & $21,852,005,542.61$ & $0.27 \%$ & 498.31 & $4 \%$ \\
\hline 2015 & $2,887,376,944,322.89$ & $20,465,191,131.48$ & $0.71 \%$ & 466.69 & $-6 \%$ \\
\hline 2016 & $5,127,906,770,545.73$ & $16,905,670,532.35$ & $0.33 \%$ & 385.52 & $-17 \%$ \\
\hline 2017 & $2,423,254,548,829.83$ & $16,939,816,338.01$ & $0.70 \%$ & 386.29 & $0 \%$ \\
\hline 2018 & $2,537,030,215,559.44$ & $16,386,051,357.43$ & $0.65 \%$ & 373.67 & $-3 \%$ \\
\hline
\end{tabular}

* Committed expense values, updated by the IGP-M (FGV), for 01/2019.

Source: Elaborated by the authors based on the National Treasury/Finbra.

The analysis of social assistance spending is useful to show the evolution of expenditures and budgetary effort in the area, however the pattern of spending may not keep up with demographic changes. The analysis of per capita spending can assist in understanding whether the amount allocated in the sector is close to meeting the needs of the population and indicates the effort made by the government in the provision of public services (OLIVEIRA, 1999).

The data below show that spending on social assistance per capita in the period increased, from BRL 24.11 in 2005, to BRL 79.73, in 2018. This growth, however, accompanied the increase in general spending per capita of the states, which may indicate that it was a general variation in the execution of resources, and not necessarily a gain for the sector.

Table 2

Evolution of spending on social assistance and total spending per capita in the 26 Brazilian states from 2005 to 2018

\begin{tabular}{|c|c|c|c|c|c|c|}
\hline Year & $\begin{array}{c}\text { Resident population } \\
\text { (except DF) }\end{array}$ & $\begin{array}{l}\text { Social Assistance } \\
\text { Spending* }\end{array}$ & $\begin{array}{l}\text { N. Social Assistance } \\
\text { Expenditure Index } \\
(2005=100)\end{array}$ & $\begin{array}{c}\text { Yearly } \\
\text { evolution \% }\end{array}$ & $\begin{array}{l}\text { Total spend } \\
\text { per capita* }\end{array}$ & $\begin{array}{c}\text { Index number } \\
\text { Total spending } \\
(2005=100)\end{array}$ \\
\hline 2005 & $181,851,156$ & 24.11 & 100 & - & $3,135.35$ & 100 \\
\hline 2006 & $184,386,778$ & 26.56 & 110 & $12 \%$ & $3,413.36$ & 108.87 \\
\hline 2007 & Not available & $\mathrm{N} / \mathrm{A}$ & $\mathrm{N} / \mathrm{A}$ & $\mathrm{N} / \mathrm{A}$ & $\mathrm{N} / \mathrm{A}$ & $\mathrm{N} / \mathrm{A}$ \\
\hline 2008 & $187,047,847$ & 26.09 & 108 & $1 \%$ & $4,006.75$ & 127.79 \\
\hline 2009 & $188,873,745$ & 29.32 & 122 & $13 \%$ & $3,959.16$ & 126.28 \\
\hline 2010 & Not available & $\mathrm{N} / \mathrm{A}$ & N/A & $\mathrm{N} / \mathrm{A}$ & N/A & $\mathrm{N} / \mathrm{A}$ \\
\hline 2011 & $189,769,289$ & 35.59 & 148 & $9 \%$ & $4,513.45$ & 143.95 \\
\hline 2012 & $191,255,483$ & 34.43 & 143 & $-3 \%$ & $4,762.24$ & 151.89 \\
\hline 2013 & $198,242,953$ & 106.22 & 440 & $220 \%$ & $4,805.08$ & 153.26 \\
\hline
\end{tabular}


Continuation

\begin{tabular}{c|c|c|c|c|c|c}
\hline Year & $\begin{array}{c}\text { Resident population } \\
\text { (except DF) }\end{array}$ & $\begin{array}{c}\text { Social Assistance } \\
\text { Spending* }\end{array}$ & $\begin{array}{c}\text { N. Social Assistance } \\
\text { Expenditure Index } \\
(2005=100)\end{array}$ & $\begin{array}{c}\text { Yearly } \\
\text { evolution \% }\end{array}$ & $\begin{array}{c}\text { Total spend } \\
\text { per capita* }\end{array}$ & $\begin{array}{c}\text { Index number } \\
\text { Total spending } \\
(2005=100)\end{array}$ \\
\hline 2014 & $199,916,190$ & 109.31 & 453 & $4 \%$ & $40,867.71$ & 1303.45 \\
\hline 2015 & $201,535,219$ & 101.55 & 421 & $-6 \%$ & $14,326.91$ & 456.95 \\
\hline 2016 & $203,104,216$ & 83.24 & 345 & $-17 \%$ & $25,247.66$ & 805.26 \\
\hline 2017 & $204,621,485$ & 82.79 & 343 & $0 \%$ & $11,842.62$ & 377.71 \\
\hline 2018 & $205,520,197$ & 79.73 & 331 & $-3 \%$ & $12,344.43$ & 393.72 \\
\hline
\end{tabular}

* Committed expense values, updated by the IGP-M (FGV), for 01/2019.

Source: Elaborated by the authors based on the National Treasury/Finbra.

It is also interesting to assess the variation in spending between the states of the federation, as pointed out in the literature (SILVA, 2015; SOUZA, 2018). The table below points out that there are differences between the Brazilian regions. In addition to being the region with the highest percentage of spending in the sector in relation to the total, the North saw an increase in spending on AS between 2005 and 2018 (0.56\%), Midwest, Northeast and Southeast had falls and the South maintained almost the same proportion (it grew $0.04 \%$ ).

Comparing the expenditures made in AS to the average percentage of people vulnerable to poverty, potential audience for this social policy, it is observed that the North and Northeast regions, which concentrate more population in this situation, also have the highest proportional expenses. The Midwest and Southeast have similar averages of people vulnerable to poverty, but the former spent proportionately twice as much as the latter in 2018. The South and Southeast had similar spending percentages in 2005. In the case of the former, however, there was a maintenance of the proportion, with a small increase; in the latter, a big drop, losing almost half of its proportional importance in relation to total spending.

Table 3

Spending on social assistance by region in 2005 and 2018

\begin{tabular}{c|c|c|c|c|c|c}
\hline Region & $\begin{array}{c}\text { Average \% of } \\
\text { vulnerable to } \\
\text { poverty 2010 }\end{array}$ & $\begin{array}{c}\text { Social assistance spending } \\
\text { in 2005* } \\
\text { (BRL) }\end{array}$ & $\begin{array}{c}\text { Spending on social } \\
\text { assistance in 2018* } \\
\text { (BRL) }\end{array}$ & $\begin{array}{c}\text { Variation } \\
\%\end{array}$ \\
\hline Midwest & 26.02 & $350,968,768.80$ & $0.95 \%$ & $1,307,676,617.81$ & $0.74 \%$ & $-0.21 \%$ \\
\hline Northeast & 46.82 & $1,266,564,65.51$ & $1.16 \%$ & $4,598,998,571.85$ & $0.87 \%$ & $-0.29 \%$ \\
\hline North & 54.93 & $542,867,314.06$ & $1.27 \%$ & $4,087,954,958.25$ & $1.83 \%$ & $0.56 \%$ \\
\hline Southeast & 23.51 & $1,716,245,393.67$ & $0.58 \%$ & $3,726,293,635.72$ & $0.31 \%$ & $-0.27 \%$ \\
\hline South & 16.9 & $508,564,394.92$ & $0.59 \%$ & $2,665,127,573.80$ & $0.64 \%$ & $0.04 \%$ \\
\hline Total & N/A** & $4,385,210,516.95$ & $0.77 \%$ & $16,386,051,357.43$ & $0.65 \%$ & $-0.12 \%$ \\
\hline
\end{tabular}

* Committed expense values, updated by the IGP-M (FGV), for 01/2019.

$* * \%$ of vulnerable to poverty in Brazil $=32.56$

Source: Elaborated by the authors based on Atlas of Human Development and National Treasury/Finbra.

The analysis of spending between states points to a great heterogeneity. The comparison between the percentages of spending on social assistance in the two years shows that twelve states had expenditures equal to or below the average $(0.77 \%)$, in 2005, and thirteen, in 2018 (average of 0.65\%). Of these, eight states maintained below-average spending in those years: Bahia, Minas Gerais, Mato Grosso, Pernambuco, Rio de Janeiro, Rondônia, Rio Grande do Sul and Santa Catarina. Among the lowest proportions of expenditures, Minas Gerais, Mato Grosso and Pernambuco; among the largest, Amapá, Mato Grosso do Sul, Paraíba and Rio Grande do Norte. Most states (17) had a reduction in spending between 2005 and 2018. Among the states that experienced growth, Maranhão and Pará stand out, with a variation of $1.15 \%$ and $2.71 \%$, respectively. 
Graph 1

Proportion of expenditure on social assistance in relation to the total by state, in 2005 and 2018

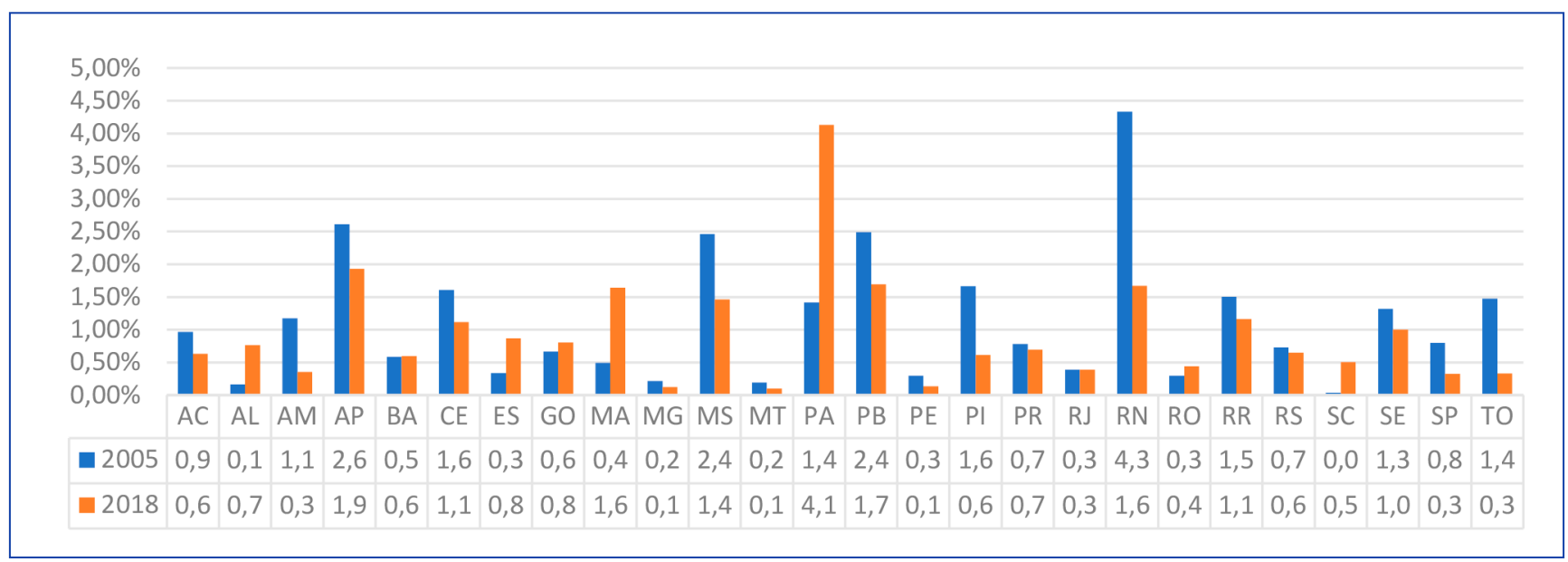

Source: Elaborated by the authors based on the National Treasury/Finbra.

\section{SHARED FINANCING IN SOCIAL ASSISTANCE: FRAGILITIES IN STATE-LEVEL CO-FINANCING}

In addition to the low participation of states in spending on social assistance, the non-fulfillment by all states of the co-financing responsibility by means of fund-to-fund transfers, which corresponds to the pillar of the sector's shared financing model. In 2010, five (19.2\%) states reported having co-financed exclusively in fund-by-fund mode; ten (38.5\%), only by covenant; eight (30.8\%), through both; and three (11.5\%) states (Acre, Piauí and Goiás) did not make any transfers to the municipalities within their jurisdiction.

In 2018, progress can be noted in the institution of on-lending transfers: of the 26 states, eighteen (69.2\%) co-financed fund-to-fund only; two (7.7\%) use both modalities; two others (7.7\%) informed that they had not carried out any type of co-financing (Roraima and Amazonas); and four (15.4\%) did not inform (Acre, Piauí, Rondônia and Tocantins).

There are, however, weaknesses related to the form of organization, coverage and regularity of co-financing. The transfer of resources by the states does not cover all types of services offered by the municipalities or the total number of municipalities under the jurisdiction of each one of them. In 2010, of the 23 states that co-financed, 21 made transfers to basic social protection; sixteen, to special social protection of medium complexity; twelve, to special social protection of high complexity; and nine, to individual benefits. In 2018, this situation changed a little: eighteen states reported that they transferred funds for basic social protection; nineteen, to special social protection of medium complexity; fifteen, that of high complexity; twelve, to individual benefits; and five, encouraging management.

The rates of coverage of the state co-financing in relation to the total number of municipalities reveal an important improvement in coverage, despite not being consolidated in all states. In 2010, only $42 \%$ of Brazilian municipalities received co-financing from fund to fund, and $20.4 \%$ received via a covenant from state entities. In 2018 , states reported that $81 \%$ of municipalities were co-financed from fund to fund and only $2 \%$ through a covenant, eleven states made fund-to-fund transfers to all their municipalities. 
Table 4

Number of municipalities receiving co-financing of social assistance by state and type, in 2010 and 2018

\begin{tabular}{|c|c|c|c|c|c|c|c|c|c|c|}
\hline State & $\begin{array}{c}\text { Total } \\
\text { municipalities } \\
2010\end{array}$ & $\begin{array}{l}\text { Fund to } \\
\text { fund in } \\
2010\end{array}$ & $\%$ & $\begin{array}{c}\text { Covenant in } \\
2010\end{array}$ & $\%$ & $\begin{array}{c}\text { Total } \\
\text { municipalities } \\
2018 \\
\end{array}$ & $\begin{array}{l}\text { Fund-to- } \\
\text { fund in } \\
2018\end{array}$ & $\%$ & $\begin{array}{l}\text { Covenant } \\
\text { in } 2018\end{array}$ & $\%$ \\
\hline Acre & 22 & 0 & $0 \%$ & 0 & $0.0 \%$ & 22 & $N / R$ & $N / R$ & $N / R$ & $\mathrm{~N} / \mathrm{R}$ \\
\hline Alagoas & 102 & 48 & $47 \%$ & 130 & $127.5 \% *$ & 102 & 83 & $81 \%$ & 0 & $0 \%$ \\
\hline Amapá & 16 & 16 & $100 \%$ & 16 & $100.0 \%$ & 16 & 16 & $100 \%$ & 0 & $0 \%$ \\
\hline Amazonas & 62 & 0 & $0 \%$ & 16 & $25.8 \%$ & 62 & 0 & $0 \%$ & 0 & $0 \%$ \\
\hline Bahia & 417 & 417 & $100 \%$ & 0 & $0.0 \%$ & 417 & 417 & $100 \%$ & 0 & $0 \%$ \\
\hline Ceará & 184 & 103 & $56 \%$ & 81 & $44.0 \%$ & 184 & 173 & $94 \%$ & 0 & $0 \%$ \\
\hline $\begin{array}{c}\text { Espírito } \\
\text { Santo }\end{array}$ & 78 & 74 & $95 \%$ & 78 & $100.0 \%$ & 78 & 78 & $100 \%$ & 0 & $0 \%$ \\
\hline Goiás & 246 & 0 & $0 \%$ & 0 & $0.0 \%$ & 246 & 121 & $49 \%$ & 91 & $37 \%$ \\
\hline Maranhão & 217 & 55 & $25 \%$ & 3 & $1.4 \%$ & 217 & 1 & $0 \%$ & 0 & $0 \%$ \\
\hline Mato Grosso & 141 & 141 & $100 \%$ & 0 & $0.0 \%$ & 141 & 141 & $100 \%$ & 0 & $0 \%$ \\
\hline $\begin{array}{l}\text { Mato Grosso } \\
\text { do Sul }\end{array}$ & 78 & 78 & $100 \%$ & 19 & $24.4 \%$ & 79 & 79 & $100 \%$ & 0 & $0 \%$ \\
\hline Minas Gerais & 853 & 180 & $21 \%$ & 273 & $32.0 \%$ & 853 & 853 & $100 \%$ & 0 & $0 \%$ \\
\hline Pará & 143 & 0 & $0 \%$ & 13 & $9.1 \%$ & 144 & 144 & $100 \%$ & 0 & $0 \%$ \\
\hline Paraíba & 223 & 0 & $0 \%$ & 25 & $11.2 \%$ & 223 & 223 & $100 \%$ & 0 & $0 \%$ \\
\hline Paraná & 399 & 0 & $0 \%$ & 59 & $14.8 \%$ & 399 & 399 & $100 \%$ & 0 & $0 \%$ \\
\hline Pernambuco & 185 & 0 & $0 \%$ & 175 & $94.6 \%$ & 185 & 184 & $99 \%$ & 0 & $0 \%$ \\
\hline Piauí & 224 & 0 & $0 \%$ & 0 & $0.0 \%$ & 224 & $N / R$ & $N / R$ & $N / R$ & $\mathrm{~N} / \mathrm{R}$ \\
\hline $\begin{array}{l}\text { Rio de } \\
\text { Janeiro }\end{array}$ & 92 & 0 & $0 \%$ & 92 & $100.0 \%$ & 92 & 92 & $100 \%$ & 0 & $0 \%$ \\
\hline $\begin{array}{c}\text { Rio Grande } \\
\text { do Norte }\end{array}$ & 167 & 25 & $15 \%$ & 0 & $0.0 \%$ & 167 & 43 & $26 \%$ & 0 & $0 \%$ \\
\hline $\begin{array}{c}\text { Rio Grande } \\
\text { do Sul }\end{array}$ & 496 & 441 & $89 \%$ & 0 & $0.0 \%$ & 497 & 489 & $98 \%$ & 0 & $0 \%$ \\
\hline Rondônia & 52 & 0 & $0 \%$ & 25 & $48.1 \%$ & 52 & $N / R$ & $N / R$ & $N / R$ & $\mathrm{~N} / \mathrm{R}$ \\
\hline Roraima & 15 & 0 & $0 \%$ & 15 & $100.0 \%$ & 15 & 0 & $0 \%$ & 0 & $0 \%$ \\
\hline $\begin{array}{c}\text { Santa } \\
\text { Catarina }\end{array}$ & 293 & 130 & $44 \%$ & 0 & $0.0 \%$ & 295 & 283 & $96 \%$ & 0 & $0 \%$ \\
\hline São Paulo & 645 & 632 & $98 \%$ & 21 & $3.3 \%$ & 645 & 644 & $100 \%$ & 44 & $7 \%$ \\
\hline Sergipe & 75 & 0 & $0 \%$ & 46 & $61.3 \%$ & 75 & 37 & $49 \%$ & 0 & $0 \%$ \\
\hline Tocantins & 139 & 0 & $0 \%$ & 46 & $33.1 \%$ & 139 & $N / R$ & $N / R$ & $N / R$ & $\mathrm{~N} / \mathrm{R}$ \\
\hline Total & 5,564 & 2,340 & $42 \%$ & 1,133 & $20.4 \%$ & 5,569 & 4,500 & $81 \%$ & 135 & $2 \%$ \\
\hline
\end{tabular}

* The percentage greater than $100 \%$ is probably due to a filling error by the state.

Source: Elaborated by the authors based on SUAS State Management Census/MC. 


\section{CONCLUSION}

This article aimed to analyze the degree, the variation and the determinants of the co-responsibility of the financing in the scope of the PAS by the state entities. Bearing in mind that social assistance funds are one of the main instruments for financing this policy, which is strongly regulated, assuming the role of inducing adherence by subnational entities to its model, the conformation of Feas was analyzed in view of the provisions of the regulations and the financing model of SUAS. In general, the Feas compliance matured, although there were still weaknesses in its operationalization. The state management bodies created institutionalities foreseen in the SUAS regulations in the analyzed period, as the institution of formal and informal sectors of financial management and definition of the portfolio managers as budget decision makers of the fund. In the operationalization of the financing, although the Feas are special funds, this did not imply the application of the total resources of the sector in them, which may indicate the persistence of the presence of parallel funds, historical in the field of PAS.

It was expected that the institutional maturity and the compliance of the funds would correspond to an increase in the volume of expenditures applied in the sector. Despite the $273.67 \%$ growth in absolute spending on social assistance, data from the National Treasury from 2005 to 2018 revealed a drop in budgetary effort, from $0.77 \%$ to $0.65 \%$. This trajectory presented a great oscillation, but the consolidated data on the per capita spending of state entities demonstrate that the oscillations of spending in the sector, in the general framework, they followed the fluctuations in total spending.

The analysis by regions and states, in turn, demonstrated, as already observed in previous studies (SILVA, 2015; SOUZA, 2018), a great heterogeneity in the allocation of resources in the PAS between the states. This result points out that the strengthening of institutional and regulatory compliance of the Feas did not necessarily generate greater financial execution in the policy and, consequently, direct impacts on expansion and qualification. The data organized by regions showed that there are important differences in the evolution of the proportional expenditure in PAS between them, with the North having the highest growth $(0.56 \%)$ and the Northeast and Southeast, with the greatest reduction $(-0.29 \%$ and $-0.27 \%)$. It is interesting to note that the North and Northeast regions, with the highest concentration of people vulnerable to poverty, potential public of PAS, showed a higher proportion of spending in the sector in relation to the total. This may suggest that social demand appears to have a political incentive effect for states to assume the costs of their role in co-financing social assistance offers.

Finally, it is noteworthy that the institutional maturity of the Feas was accompanied by the assumption by the state governments, of their responsibility for fund-to-fund co-financing to municipalities under its jurisdiction, but in a partial manner. Despite the fact that coverage has increased considerably - increasing from $42 \%$ of municipalities that received fund-to-fund transfers in 2005 to $81 \%$ in 2018 -, only eleven states co-financed all of their municipalities in this modality in 2018. Once again, heterogeneities are observed between the entities. Minas Gerais and Mato Grosso, for example, are among the states with the lowest proportional expenditures, but have reported co-financing, since 2010, in all their municipalities, while Paraíba and Mato Grosso do Sul had higher proportional spending and co-financed all municipalities in 2018. Maranhão, on the other hand, showed a significant increase in the proportion of resources in the sector between 2005 and 2018 (from 0.49\% to $1.64 \%)$, but reported co-financing only one municipality in 2018.

In view of the analysis of the bibliography and the empirical results, it is concluded that SUAS has important federative coordination and induction mechanisms that led to the creation of institutionality through Feas. However, taking into account that the design of PAS delegated residual and discretionary role to the states, such mechanisms generated heterogeneous effects among them, especially in the performance of financing, the focus of this article. The relevance of the development of studies that deepen the understanding of the reasons why the states present such heterogeneous performances is highlighted, analyzing the literature on the role of state entities in federative contexts. Implementation costs versus expected low political returns, since it is up to the municipalities to implement the vast majority of services to the population, they can be important variables to be further explored, because, as the results show, the regions with the highest concentration of population vulnerable to poverty presented higher proportional expenses in the sector. It would also be important to carry out future research on the relationship between the political party factor, the volume of investments in the sector and the federal responsibilities, as suggested in previous studies (SILVA, 2015; SOUZA, 2018). 


\section{REFERENCES}

ABRUClO, F. L. Para além da descentralização: os desafios da coordenação federativa no Brasil. In: FLEURY, S. (Org.). Democracia, descentralização e desenvolvimento: Brasil e Espanha. Rio de Janeiro: Editora FGV, 2006.

ALMEIDA, M. T. Federalismos e políticas sociais. In: AFFONSO, R. B. A.; SILVA, P. L. B (Orgs.). Descentralização e políticas sociais. São Paulo: Fundap, 1996.

ARRETCHE, M. Mitos da descentralização: mais democracia e eficiência nas políticas públicas? Revista Brasileira de Ciências Sociais, ano 11, n. 31, jun. 1996.

ARRETCHE, M. Estado federativo e políticas sociais: determinantes da descentralização. Rio de Janeiro: Revan; São Paulo: Fapesp, 2000.

ARRETCHE, M. Federalismo e políticas sociais no Brasil: problemas de coordenação e autonomia. In: SARAIVA, E; FERRAREZI, E. (Orgs.). Políticas públicas: coletânea. Brasília, DF: Enap, 2006.

ARRETCHE, M. Federalismo e igualdade territorial: uma contradição em termos? Dados - Revista de Ciências Sociais, Rio de Janeiro, v. 53, n. 3, p. 587-620, 2010.

BRASIL. Política Nacional de Assistência Social 2004 e Norma Operacional Básica do Suas. Brasília, DF: MDS, 2005.

BRASIL. Norma Operacional Básica do Suas 2012. Brasília, DF: MDS, 2013.

FRANZESE, C.; ABRUCIO, F. L. A combinação entre federalismo e políticas públicas no Brasil pós-1988: os resultados nas áreas de saúde, assistência social e educação. In: FRANZESE, C. et al. Reflexões para Ibero-América: avaliação de programas sociais. Brasília, DF: Enap, 2009.

GOMES, G. M.; MACDOWELL, M. C. Descentralização política, federalismo fiscal e criação de municípios: o que é mau para o econômico nem sempre é bom para o social. Brasília, DF: Ipea, TD 706, 2000.

JACCOUD, L; LICIO, E. C.; LEANDRO, J. G. Implementação e coordenação de políticas públicas em âmbito federativo: o caso da Política Nacional de Assistência Social. In: XIMENES, D. de A. (Org.). Implementação de políticas públicas: questões sistêmicas, federativas e intersetoriais. Brasília, DF: Ipea, Enap, 2018.
KHAIR, A. A questão fiscal e o papel do Estado. São Paulo: Fundação Perseu Abramo, 2013.

MESQUITA, A. C. S.; MARTINS, R. F.; CRUZ, T. M. E. Cofinanciamento e responsabilidade federativa na política de assistência social. Brasília, DF: Ipea, TD 1724, 2012.

MONTEIRO NETO, A. Governos estaduais no federalismo brasileiro: capacidades e limitações no cenário atual. Rio de Janeiro: Ipea, TD 1894, 2013.

OLIVEIRA, F. A. de. Evolução, determinantes e dinâmica do gasto social no Brasil (1980-1996). Brasília, DF: Ipea, TD 649, 1999.

PALOTTI, P. L. M.; COSTA, B. L. D. Relações intergovernamentais e descentralização: uma análise da implementação do Suas em Minas Gerais. Revista de Sociologia e Política, Curitiba, v. 19, n. 39, p. 211235, jun. 2011.

REZENDE, F. Federalismo fiscal: em busca de um novo modelo. In: OLIVEIRA, R. P. de.; SANTANA, W. (Orgs.). Educação e federalismo no Brasil: combater as desigualdades, garantir a diversidade. Brasília, DF: Unesco, 2010.

SILVA, A. L. N. Os estados no Suas: uma análise da capacidade institucional dos governos estaduais na assistência social. Revista de Administração Pública, Rio de Janeiro, v. 49, n. 5, p. 167-1192, set./out. 2015.

SOUZA, C. Governos locais e gestão de políticas sociais universais. São Paulo em Perspectiva, São Paulo, v. 18, n. 2, p. 27-41, 2004.

SOUZA, C. Federalismo e capacidades estatais: o papel do Estadomembro na política de assistência social. In: PIRES, R.; LOTTA, G.; OLIVEIRA, V. E. de (Orgs.). Burocracia e políticas públicas no Brasil: interseções analíticas. Brasília, DF: Ipea, 2018.

SPOSATI, A. Financiamento e política pública de assistência social. Revista Parlamento e Sociedade, São Paulo, v. 4, n. 7, p. 103-120, July/Dec. 2016.

TAVARES, G. de C. O financiamento da política de assistência social na era Suas. In: MDS; UNESCO. Concepção e gestão da proteção social não contributiva no Brasil. Brasília, DF: Ministério do Desenvolvimento Social e Combate à Fome; Organização das Nações Unidas para a Educação, a Ciência e a Cultura, 2009. 
Master in Public Administration from Fundação João Pinheiro (FJP); Director of Gestão do Suas da Prefeitura de Belo Horizonte, Belo Horizonte - MG, Brazil. E-mail: isabelavasconcelos12@gmail.com

Bruno Lazzarotti Diniz Costa

ORCID: https://orcid.org/0000-0001-5972-4175

Ph.D. in Sociology and Politics from the Federal University of Minas Gerais (UFMG); Researcher at Fundação João Pinheiro (FJP), Belo Horizonte - MG,

Brazil. E-mail: bruno.diniz@fjp.mg.gov.br 